\title{
Problem of Intellectual Doubles in Contemporary Research of Russian History of Philosophy (an Example of Russian Narodism)
}

\author{
O. Marchevsky \\ University of Presov \\ Ul. 17. novembra 15, 08001 Prě̌ov, Slovakia
}

The paper enters contemporary discourse concerning the examination of history of Russian philosophy, which initiates a new reading of the Russian thinkers' works. These contemporary examinations problematize the phenomenon of so called intellectual doubles as well. The contribution proceeds from the definition of these issues which was published in journal Problems of Philosophy (Voprosy filosofii) by M. A. Maslin in 2013. In this work, Maslin mentions A. I. Herzen among the examples of intellectual doubles phenomenon, who is one of the founders of the Russian Narodism. Following from this basis, the contribution shifts an attention toward issues of intellectual doubles in the context of the Russian Narodism. The work represents an endeavour to deepen the existing problematization of this phenomenon on the basis of examination the N. K. Mikhailovsky's creative legacy. There can be found two faces in works of this Narodnik thinker. The first one can be figuratively designed as a Petersburgian and the second one as a Yaltian. These designations are borrowed from the notes of Sergey Elpatevsky, who had been Mikhailovsky's friend. The two faces express the specificity of the problem of doubleness in Mikhailovsky and his qualitative shift in relation to contemporary examinations of the reflected phenomenon.

Keywords: Russian philosophy, A.I. Herzen, Russian Narodism, N.K. Mikhailovsky

\section{Article history:}

The article was submitted on 03.10.2019

The article was accepted on 15.01.2020

For citation: Marchevsky O. Problem of Intellectual Doubles in Contemporary Research of Russian History of Philosophy (an Example of Russian Narodism). RUDN Journal of Philosophy. 2020; 24 (2): 181-186. DOI: 10.22363/2313-2302-2020-24-2-181-186

This article reacts to one of the actual problems in the field of examination of the legacy of Russian thought. The point is an issue or phenomenon of so called intellectual doubles. The plenary lecture of professor M. A. Maslin Russian philosophy as a dialogue of world-views, delivered at the Congress of Russian

(C) Marchevsky O., 2019

(c) () This work is licensed under a Creative Commons Attribution 4.0 International License https://creativecommons.org/licenses/by/4.0/ 
Philosophical Society in Nizhny Novgorod on 27th June, 2012, represents important milestone in forming the discussion. In his interpretation of some Russian thinkers, Maslin pointed out on a problem of so called double consisting of certain tendentious typecasting of some Russian philosophers and he adverted to existence of their authentic faces which still wait for discovery. The authentic face can be uncovered only through continual, new, and unprejudiced reading of Russian thinkers' works. According to Maslin, one of the thinkers considerably affected by the problem of double is A. I. Herzen to whom he paid key attention in his lecture along with M. V. Lomonosov. Maslin described Herzen together with Dostoyevsky and Tolstoy as the greatest analysts of democracy among all the Russian thinkers and he declared his conviction that just these two thinkers formulated questions and evaluations regarding true nature of democracy most precisely. They uncovered difficulties which democracy may bring to social life. During my study, I have met with several works which encourage repeated and thorough reading the works of thinkers of the second half of the 19th century, including Narodniks [e.g. 8; 10]. Professor of Moscow State University, Viacheslav Nikolaevich Zhukov, expressed himself just in relation to this distinct intellectual element of the second half of the 19th century, during the work of the round table on 15th September, 2010 in Solzhenitsyn Centre of Russian Emigré Studies in Moscow. He analysed the character of examination of Chernyshevsky's works from the Soviet era to the present and pointed to necessary need of repeated and new reading of these works, despite the fact that about 400 dissertations devoted to the native of Saratov have been written and defended since the Soviet era. Zhukov emphasized that one quite misrepresented picture of this thinker is often used to appear.

In order to express the sprit of intended new reading, let me refer to Lalayan's idea: "New reading of works of the most distinctive researchers and social-political public agents may show to be useful in contemporary conditions" [3. P. 4]. Lalayan's work is inspirational also for another reason: Lalayan analyses economic aspects in Narodniks' thought.

The need to thorough questioning the nature of Narodnik identity and its creative and philosophical legacy emerges from confrontation with these attitudes.

In my view, Zhukov's opinion regarding the one persisting tendentious interpretation does not fit only to the one of Narodism's precursor, but it may be broaden over the whole movement. It seems to me that Narodism contains more than just an ideological support of radical terroristic acts, more than an effort to rationalize them and to excuse them in front of the public. Russian Narodism is more than a stillborn intellectual endeavour on the way to Lenin. Different scope of the Narodism is represented by the conception of subjective method elaborated by N. K. Mikhaylovsky and P. L. Lavrov. This conception was further developed by N. A. Karayev and it supported a critical discussion with P. N. Tkachev. There are interesting reflections concerning philosophy of history and anthropological considerations as well as the conception of an individual who differs from a man in that he actively participates and reshapes the public affairs and takes full responsibility for his action. 
I would like to deepen the reflections on the issue of intellectual doubles in the context of Narodism. For this intention, I will use an example of creative legacy of Mikhaylovsky. More precisely, I would like to pay an attention to authenticity, true face or message of his intellectual achievements. In this sense, I will point out to certain vagueness, controversies, even conflicting tendencies contained within the results of his creative activities. The question is what do these antagonisms mean, not only within his writings, but also in the context of his lived personal and social experience? Study of available primary works as well as of secondary literature uncovered as an issue, as a distinctive line of the problem of doubleness, the fact that the Narodism thinker, Mikhaylovsky, becomes a double of himself. His written works, life, social contacts produce contradictory opinion stances. By contrast to "Maslinian model" of doubleness, I focus my attention on two faces of one thinker which follow from the study of his own legacy. In this sense, the work of Blokhin (2004) is notably useful. It is interesting with its historical reflections in the spirit of new readings of Narodism. It is fundamental also due to a number of direct archive materials and notes of Mikhaylovsky's contemporaries which are almost impossible to access beyond the Russia's bordersf. In my attempt to outline the frameworks of authentic face in Mikhaylovsky, I will use figurative differentiation between Mikhaylovsky-Petersburgian and Mikhaylovsky-Yaltian. Sergey Yelpatevsky writes about Mikhaylovsky and his behaviour at these two places. Yelpatevsky, a doctor and a friend of Mikhaylovsky, recalls his stay in Yalta where he had been treated for heart problems from spring of 1896 to 1897 as follows: "In Yalta, Nikolay Konstantinovich was not Petersburgian Mikhaylovsky - terse, formal, alert, it seemed to me, always ready to repulse possible attack - in Yalta, he was trustful, moderate, considerate, I would say he had a rest from a necessity to deflect and inflict the strikes" (quoted from [1. P. 203-204]). In my opinion, this different behaviour of Mikhaylovsky can be reflected also in his creative activities.

If we take a closer look at Mikhaylovsky's works, we can see that the distinctive place within them is held by the conception of subjective method, the method of which Mikhaylovsky is one of the principal initiators. The subjective method would represent the Yaltian face of Mikhaylovsky. Mikhaylovsky gives an apt and brief account of the nature of the method as follows: "hitting the subjective element, i.e. the best feelings and wishes" [5. P. 137]. Important role of the subjective method is declared also by Russian expert on Mikhaylovsky and editor of the latest edition of his collected works, already mentioned professor Blokhin, who notes: "It became the starting point of historical epistemology of sociologist, some kind of bearing construction not only for philosophy of history, but also for whole social-political program of this thinker" [2. P. 54]. According to Mikhaylovsky, emotions, desires and wishes, own to everyone but still different from one man to another, are something one cannot extricate from, something what has to be taken into account in considering the historical and social events. Mikhaylovsky's fundamental assumption for these methodological reflections is formulated as follows: “... everything is created for a man, absolutely by right, however not in objective but in subjective sense. It is not given to a man; everything 
has to be acquired by sweat and blood. But in regard of man's interests, he situates himself to the centre of nature which he adapts to himself by the strength of his consciousness" [6. P. 271]. Influence of emotions, desires, and particular goals is not something what should be supressed, instead it should be reflected as something what we cannot extricate from, and what causes that we are not able to clearly refer about the sense of history and final goal of history or forming the society. From the perspective of subjective method, we should come to realize that every effort to do any social changes always appertains only to certain period. We can never formulate absolutely and finally rightful goal for human history. In his work What is Progress?, Mikhaylovsky discusses his opinion as just one among many possible ones, as one which he just offers to contemporary social discussion.

In order to problematize the authentic face of Mikhylovsky through the way of possible contrasts on the background of principles of subjective method, I will firstly outline Mikhaylovsky's relation to the real political praxis. Frequent question in the context of Mikhaylovsky and other Narodniks is their relationship to revolutionary radicalism. What makes position of Mikhaylovsky more interesting is the fact that he had never situated himself into a position of an ideologist of radical party the Narodnaya Volya and he had never been direct editor of the journal of the same name. However he was always close to the party; he tried to excuse even popularize its activities, committed terror, in front of the general public. It is noteworthy that someone who insists on creative discussion is able to excuse terroristic acts. I my view, this is particularly serious topic which would need detailed and individual elaboration. Within my reflection, I reserve myself only to indication of this thematic field through which the profile of Mikhaylovsky can be coloured on the background of subjective method. Nonetheless, I am convinced that this point represents the substantial tendency and cannot be overlooked in relation to Mikhaylovsky.

In his dialogue with E. K. Pimenova which is situated in her work Past Days (Дни минувшие), Mikhaylovsky expressed himself as follows: "In literary work, autocracy is inevitable. Contradictions cannot be allowed." [9. P. 142].

Mikhaylovsky's resolute rejection of different opinions can be seen also in his evaluation of the work Without a Road (Без дороги) written by a young writer Vikenty Veresaev. Blokhin writes: "Mikhaylovsky repudiated the young writer just because of opinion disagreement" [1. P. 201]. Subsequently he writes about the nature of this dispute: "This story with Veresaev is typical for the epoch. Mikhaylovsky did not want to admit that different doctrine, ideology, and eventually different rulers of dumas were coming to substitute him" [1. P. 202].

Taking into consideration these Blokhin's observations as well as Mikhaylovsky's opinions, the following question arises: Are Mikhaylovsky's extensive theoretical writings just some kind of veil by which he wanted to cover his genuine need to be ideological leader of Russia in turbulent times of the second half of the 19th century? And primarily, it is not clear why he would elaborate the conception of subjective method which was not only momentary vagary, but the fundament, the skeleton of his legacy of thought, the position he never resigned from and never initiated its revision? 
Why Mikhaylovsky was not able to follow the principles of subjective method and he became the proponent of autocracy in literature?

Perhaps, two faces of Mikhaylovsky could be seen as a product of inability or unwillingness of his contemporaries to understand and accept his attitudes in horizon of the period at that time. Therefore the realization of principles of subjective method had to be "postponed" to future and Mikhaylovsky had to adapt his narrative strategy to demands of the period.

\title{
References
}

[1] Blohin VV. Na perelome 1881-1904. N.K. Mihajlovskij v idejno-politicheskoj bor'be v 80-90-e gody XIX veka. Moscow: 2004. (In Russian).

[2] Blohin VV. Istoricheskaja koncepcija Nikolaja Mihajlovskogo. Moscow: 2001. (In Russian).

[3] Lalajan VS. Jelementy narodnichestva $v$ trudah jekonomistov 20-30-h godov proshlogo staletija i ih proekcija na problemy sovremennoj Rossii. St. Petersburg: 2002. (In Russian).

[4] Maslin MA. Russkaja filosofija kak dialog mirovozzrenij. Voprosy filosofii. 2013; 66(1): 43-48. (In Russian).

[5] Mihajlovskij NK. Chto takoe progress? In: Blohin VV. (ed). Izbrannye trudy. Moscow: 2010. S. 61-213. (In Russian).

[6] Mihajlovskij NK. Teorija Darvina i obshhestvennaja nauka. In: Blohin VV. (ed). Izbrannye trudy. Moscow: 2010. S. 214-399. (In Russian).

[7] Mihajlovskij NK. (c): Bor'ba za individual'nost'. In: Blohin, V. V. (ed). Izbrannye trudy. Moscow: 2010. S. 458 - 629. (In Russian).

[8] Novikova LM, Sizemskaja IN. Ocherk russkoj filosofii istorii. In: Novikova LM, Sizemskaja IN (eds). Russkaja istoriosofija. Antologija. Moscow: 2006. S. 5-69. (In Russian).

[9] Pimenova JeK. Dni minuvshie: vospominanija. Leningrad-Moscow: 1929. (In Russian).

[10] Walicki A. Zarys Myśli Rosyjskiej od Oświecenia do Renesansu Religijno-Filozoficznego. Kraków: Wydawnictwo Uniwersytetu Jagiellońskiego; 2005. (In Polish).

\section{About the author:}

Marchevský Ondrej - PhD., Department of Civil Education at the Institute of Political Sciences, Faculty of Arts, University of Prešov in Prešov (e-mail: ondrej333@gmail.com).

\section{Проблема интеллектуальных двойников в современных исследованиях по истории русской философии (на примере русского народничества)}

\section{О. Мархевский}

\author{
Прешовский университет \\ Ul. 17. novembra 15, 08001 Prešov, Slovakia
}

Статья вводит читателя в современный исследовательский дискурс по истории русской философии, инициирующий новое прочтение произведений русских мыслителей. Эти исследования проблематизируют феномен так называемых «интеллектуальных двойников». Отправной точкой статьи выступает формулировка этой проблемы, представленная в 2013 г. М.А. Маслиным в журнале «Вопросы философии». В своей работе 
Маслин упоминает А.И. Герцена, одного из основателей русского народничества, как пример феномена интеллектуальных двойников. Развивая эту тему, статья обращает внимание на проблему интеллектуальных двойников в контексте русского народничества, углубляя и усиливая проблематизацию этого феномена обращением к творческому наследию Н.К. Михайловского. В произведениях этого мыслителя-народника можно обнаружить два лица. Первое может быть метафорически определено как петербургское, а второе - как ялтинское. Эти обозначения заимствованы из заметок Сергея Елпатьевского, друга Михайловского. Двуликость выражает специфику проблемы двойников у Михайловского, а также ее качественный сдвиг по отношению к современным исследованиям описываемого феномена.

Ключевые слова: русская философия, А.И. Герцен, русское народничество, Н.К. Михайловский

\section{Список литературы}

[1] Блохин B.B. На переломе 1881-1904. Н. К. Михайловский в идейно-политической борьбе в 80-90-е годы XIX века. Москва: Издательство РУДН, 2004.

[2] Блохин В.В. Историческая концепция Николая Михайловского. Москва: ПРОБЕЛ2000, 2001.

[3] Лалаян В.С. Элементы народничества в трудах экономистов 20-30-х годов прошлого столетия и их проекция на проблемы современной России. Санкт-Петербург: Издательство СПБ гос. университета экономики и финансов, 2002.

[4] Маслин М.A. Русская философия как диалог мировоззрений // Вопросы философии. 2013. № 1. С. $43-48$.

[5] Михайловский Н.К. Что такое прогресс? // Блохин В.В. (ред.). Избранные труды. Москва: РОССПЭН, 2010. С. 61-213.

[6] Михайловский Н.К. Теория Дарвина и общественная наука // Блохин В.В. (ред.). Избранные труды. Москва: РОССПЭН, 2010. С. 214-399.

[7] Михайловский Н.К. Борьба за индивидуальность. // Блохин, В. В. (ред.). Избранные труды. Москва: РОССПЭН, 2010. С. 458-629.

[8] Новикова Л.М., Сиземская И.Н. Очерк русской философии истории // Новикова Л.М., Сиземская И.Н. (ред.). Русская историософия. Антология. Москва: РОССПЭН, 2006. С. 5-69.

[9] Пименова Э.К. Дни минувшие: воспоминания. Ленинград — Москва: Книга, 1929. Zarys Myśli Rosyjskiej od Oświecenia do Renesansu Religijno-Filozoficznego. Kraków:

\section{История статьи: \\ Статья поступила 03.10.2019 \\ Статья принята к публикации 15.01.2020}

Для цитирования: Мархевский О. Проблема интеллектуальных двойников в современных исследованиях по истории русской философии (на примере русского народничества) // Вестник Российского университета дружбы народов. Серия: Философия. 2020. T. 24. No 2. C. $181-186$. DOI: 10.22363/2313-2302-2020-24-2-181-186

\section{Сведения об авторе:}

Мархевский Ондрей - канд. философских наук, кафедра гражданского образования института политических наук, факультет искусств, Прешовский университет в Прешове (е-mail: ondrej333@gmail.com). 